\title{
Antiproliferative Effect of Metformin on the Endometrium in cases of perimenopausal bleeding
}

Ismaeil Mohammed Elgarhy, Noha Sabry, Ahmed Mohmmed elfeky

Department of Obstetrics \& Gynecology, Faculty of Medicine, Al-Azhar University

Corresponding author: Ahmed Mohmmed elfeky, Mobile: 01064112746, email: ahmedabdelmohsen20009@gmail.com

\begin{abstract}
Background: based on numerous epidemiologic and experimental studies it has been speculated that unopposed estrogen has a central role in development of endometrial benign, premalignant and malignant lesions. Endometrial cancer is the most common malignancy of the female genital tract, and the fourth most common cancer in women in developed countries. EC is the seventh most common cancer in women worldwide.

Objective: To examine the effect of metformin on disordered proliferative endometrium and simple endometrial hyperplasia in comparison with progesterone to assess metformin clinical usefulness in these situations.

Patients and Methods: All patients who referred for abnormal uterine bleeding (perimenopausal) and underwent endometrial office biopsy or D\&C in our hospital and their tissue diagnosis was disordered proliferative endometrium (DPE) or simple hyperplasia (SH) were included in this study. Past medical history gathered from patients' interview records and patients with history of metformin sensitivity, renal failure, anorexia, anemia, skin rashes, diabetes mellitus, gynecologic neoplastic disorders and patients on estrogen or progesterone were excluded. Patients who fitted with including criteria were categorized in two groups in randomized fashion.

Results: Our findings in this study revealed that metformin could be effective as well as progesterone in resolving of benign enodometrial proliferative lesions.

Conclusion: The current study showed that treatment of the patients with abnormal endometrial proliferation (DPE and $\mathrm{SH}$ ) with metformin induced endometrial atrophy and prevents abnormal cell growth and prevents perimenopausal bleeding subsequently.
\end{abstract}

Keywords: Endometrial cancer, medroxyprogesterone acetate, insulin-like growth factors.

\section{INTRODUCTION}

In light of various epidemiologic and test ponders it has been theorized that unopposed estrogen has a focal job being developed of endometrial benevolent, premalignant and threatening sores ${ }^{(\mathbf{1})}$.

Endometrial disease is the most well-known threat of the female genital tract, and the fourth most basic malignancy in ladies in created nations. EC is the seventh most normal disease in ladies around the world (2). Endometrial adenocarcinoma is gone before by a progression of histopathological change considered endometrial hyperplasia that is amiable to treatment. Endometrial hyperplasia is treated with progesterone and its engineered structure, medroxyprogesterone acetic acid derivation (MPA). MPA can likewise be utilized in cutting edge or recurrent EC, in chose cases who wish to save their ripeness ${ }^{(3)}$.

The job of progesterone on the endometrium is essentially to incite cellulary separation and to estrange estrogen intervened cell expansion. The progesterone demonstrates its antitumour impact by authoritative to the atomic receptors, and enacting the interpretation of a few qualities, which are associated with crossconverse with other flagging pathways, for example, development factors and their receptors ${ }^{(4)}$.

As of late, an expanding assortment of proof proposes that weight, diabetes and insulin obstruction are solid hazard factors for EC, and insulin-like development factors (IGFs) assume a noteworthy job in carcinogenesis and malignant growth movement ${ }^{(5)}$.

Besides, it has been demonstrated that insulin receptor quality articulation is managed all through the menstrual cycle of solid ladies, empowering insulin to influence stromal cell decidualization ${ }^{(6)}$.

In light of the connection between endometrial hyperplasia, insulin, and its middle people, insulin sensitizers has turned into the most well known subject of examination for their antiproliferative impacts ${ }^{(7)}$.

Metformin is an oral biguanide utilized in diabetes, insulin obstruction, and polycystic ovarian disorder. Ongoing reports demonstrate that metformin may diminish the neoplastic multiplication of cells by means of balancing the glucose metabolism, insulin affectability and intracellular sign pathways ${ }^{(8)}$.

All the more as of late, metformin has been accounted for to hinder the attack of human endometrial carcinoma cells, in vitro ${ }^{(9)}$.

Anovulatory cycles are normal at menarche and menopause and as a rule incite generous endometrial multiplication including disarranged proliferative endometrium and straightforward endometrial hyperplasia without atomic atypia ${ }^{(10)}$.

Drawn out anovulatory cycles due to PCO or other hyperestrogenic states, for example, estrogen discharging tumors frequently lead to expanded endometrial multiplication and cause complex hyperplasia with or without atypia, endometrial polyps or type I endometrial carcinoma ${ }^{(11)}$.

In spite of the fact that there is no uncertainty respect to job of estrogenic specialists in creating of strange endometrial multiplication, ongoing comprehension of hereditary and sub-atomic premise of endometrial carcinoma lead to another phrasing for 
favorable and genuine premalignant endometrial injury proposed by global gathering of pathologist in $2000^{(12)}$.

In light of this new order, those multiplications that speak to hormonal field impact for example confused proliferative endometrium, endometrial hyperplasia (straightforward or complex) without atomic atypia and endometrial polyp can be incorporated into generous classification while those that demonstrating hereditarily modified swarmed organs with clonal extension (endometrial intraepithelial neoplasia-EIN) arranged as evident premalignant gathering ${ }^{(13)}$.

\section{AIM OF THE WORK}

This clinical preliminary is directed to look at the impact of metformin on confused proliferative endometrium and straightforward endometrial hyperplasia in correlation with progesterone to survey metformin clinical value in these circumstances.

\section{PATIENTS AND METHODS}

All patients who alluded for irregular uterine dying (perimenopausal) and experienced endometrial office biopsy or D\&C in our medical clinic (Elhussin Hospital) and their tissue determination were confused proliferative endometrium (DPE) or basic hyperplasia (SH) incorporated into this examination. Past therapeutic history accumulated from patient meeting records and patients with history of metformin affectability, renal disappointment, anorexia, frailty, skin rashes, diabetes mellitus, gynecologic neoplastic issue and patients on estrogen or progesterone were prohibited.

\section{Ethical approval:}

The study was approved by the Ethics Board of Al-Azhar University and an informed written consent was taken from each participant in the study.

\section{RESULTS}

Table (1): Age distribution of the patients in metformin and progesterone groups

\begin{tabular}{|c|c|c|c|c|c|c|c|}
\hline & Group & Min & Max & Mean & SD & t & P-value \\
\hline \multirow{2}{*}{$\begin{array}{c}\text { Age } \\
\text { (years) }\end{array}$} & $\begin{array}{c}\text { Metformin } \\
\text { (No.=50) }\end{array}$ & 44 & 52 & 49.02 & 2.43 & \multirow{2}{*}{1.71} & \multirow{2}{*}{0.090} \\
\cline { 2 - 6 } & $\begin{array}{c}\text { Progesterone } \\
\text { (No.=50) }\end{array}$ & 46 & 54 & 49.87 & 2.50 & & \\
\hline
\end{tabular}

$\mathrm{t}$ : Independent samples t-test

Table (1) showed that the mean age in the Metformin group was $49.02 \pm 2.43$ years that ranged from (44 52) years, while the mean age in the Progesterone group was $49.87 \pm 2.50$ that ranged from (46 - 54) years with no statistical significant difference between both groups.

Table (2): Comparison between gravidity of the patients for metformin and progesterone groups

\begin{tabular}{|l|c|c|c|c|c|}
\hline & Group & Mean & SD & t & P-value \\
\hline \multirow{2}{*}{ Gravida } & Metformin (No.=50) & 3.64 & 1.83 & \multirow{2}{*}{0.51} & \multirow{2}{*}{0.608} \\
\cline { 2 - 4 } & Progesterone (No.=50) & 3.46 & 1.67 & & \\
\hline
\end{tabular}

t: Independent samples t-test

Table (2) showed that according to gravidity, no statistical significant difference was found between Metformin and Progesterone groups. 
ejhm.journals.ekb.eg

Table (3): Comparison between parity of the patients for metformin and progesterone groups

\begin{tabular}{|l|c|c|c|c|c|}
\hline & Group & Mean & SD & t & P-value \\
\hline \multirow{2}{*}{ Parity } & Metformin (No.=50) & 2.96 & 1.74 & \multirow{2}{*}{0.12} & 0.901 \\
\cline { 2 - 6 } & Progesterone (No.=50) & 3.00 & 1.47 & & \\
\hline
\end{tabular}

t: Independent samples t-test

Table (3) showed that according to parity, no statistical significant difference was found between Metformin and Progesterone groups.

Table (4): Comparison between abortion of the patients for metformin and progesterone groups

\begin{tabular}{|c|c|c|c|c|}
\hline \multirow{2}{*}{\multicolumn{2}{|c|}{ Abortion }} & \multicolumn{2}{|c|}{ Grouping } & \multirow{3}{*}{$\begin{array}{c}\text { Total } \\
53\end{array}$} \\
\hline & & Metformin (No.=50) & Progesterone No. $=50$ & \\
\hline \multirow{2}{*}{ None } & No & 21 & 32 & \\
\hline & $\%$ & 42.0 & 64.0 & 53.0 \\
\hline \multirow{2}{*}{1} & No & 25 & 14 & 39 \\
\hline & $\%$ & 50.0 & 28.0 & 39.0 \\
\hline \multirow{2}{*}{2} & No & 3 & 3 & 6 \\
\hline & $\%$ & 6.0 & 6.0 & 6.0 \\
\hline \multirow{2}{*}{3} & No & 1 & 1 & 2 \\
\hline & $\%$ & 2.0 & 2.0 & 2.0 \\
\hline \multicolumn{2}{|c|}{$X^{2}=5.39$} & \multicolumn{3}{|c|}{ P-value $=0.146$} \\
\hline
\end{tabular}

X2: Chi-square test.

Table (4) showed that after comparison between number of abortions of the patients for metformin and progesterone groups, $\mathrm{p}$ value was 0.146 which is non-significant statistically.

Table (5): Blood sugar before treatment in metformin and progesterone groups

\begin{tabular}{|c|c|c|c|c|c|}
\hline \multirow[b]{2}{*}{ Group } & \multicolumn{3}{|c|}{ BS before treatment } & \multirow[b]{2}{*}{$X^{2}$} & \multirow[b]{2}{*}{ P-value } \\
\hline & $\begin{array}{c}<126 \mathrm{mg} / \mathrm{dl} \\
\quad \text { No }(\%)\end{array}$ & $\begin{array}{c}126-200 \mathrm{mg} / \mathrm{dl} \\
\text { No }(\%)\end{array}$ & $\begin{array}{l}>200 \mathrm{mg} / \mathrm{dl} \\
\text { No }(\%)\end{array}$ & & \\
\hline Metformin (No. $=50)$ & $41(82.0)$ & $5(10.0)$ & $4(8.0)$ & \multirow{2}{*}{0.55} & \multirow{2}{*}{0.760} \\
\hline Progesterone $($ No. $=50)$ & $43(86.0)$ & $3(6.0)$ & $4(8.0)$ & & \\
\hline Total & $84(84.0)$ & $8(8.0)$ & $8(8.0)$ & & \\
\hline
\end{tabular}

X2: Chi-square test.

Table (5) showed that the majority of patients (82\%) in the metformin group and (86\%) in the progesterone group had blood sugar levels of less than $126 \mathrm{mg} / \mathrm{dl}$ before treatment with no statistical significant difference between both groups.

Table (6): Blood sugar after treatment in metformin and progesterone groups

\begin{tabular}{|c|c|c|c|c|c|}
\hline \multirow[b]{2}{*}{ Group } & \multicolumn{3}{|c|}{ BS after treatment } & \multirow[b]{2}{*}{$X^{2}$} & \multirow[b]{2}{*}{ P-value } \\
\hline & $\begin{array}{c}<126 \mathrm{mg} / \mathrm{dl} \\
\text { No }(\%)\end{array}$ & $\begin{array}{c}126-200 \mathrm{mg} / \mathrm{dl} \\
\text { No }(\%)\end{array}$ & $\begin{array}{l}>200 \mathrm{mg} / \mathrm{dl} \\
\quad \text { No }(\%)\end{array}$ & & \\
\hline Metformin (No.=50) & $44(88.0)$ & $3(6.0)$ & $3(6.0)$ & \multirow[b]{2}{*}{0.15} & \multirow[b]{2}{*}{0.926} \\
\hline $\begin{array}{l}\text { Progesterone } \\
(\text { No.=50) }\end{array}$ & $43(86.0)$ & $4(8.0)$ & $3(6.0)$ & & \\
\hline Total & $87(87.0)$ & $7(7.0)$ & $6(6.0)$ & & \\
\hline
\end{tabular}

X2: Chi-square test. Table (6) showed that the majority of patients (88\%) in the metformin group and (86\%) in the progesterone group had blood sugar levels of less than $126 \mathrm{mg} / \mathrm{dl}$ after treatment with no statistical significant difference between both groups.

Table (7): Pathology of the metformin group

\begin{tabular}{|c|c|}
\hline \multicolumn{1}{|c|}{ Pathology } & Metformin group No (\%) \\
\hline Simple hyperplasia (S.H) & $16(32.0)$ \\
\hline Disordered proliferative endometrium (D.P.E) & $34(68.0)$ \\
\hline Total & $50(100.0)$ \\
\hline
\end{tabular}

Table (7) showed that about one third (32\%) of patients in the metformin group had simple hyperplasia and the remaining $(68 \%)$ had disordered proliferative endometrium. 
Table (8): Pathology of the progesterone groups

\begin{tabular}{|c|c|}
\hline \multicolumn{1}{|c|}{ Pathology } & Progesterone group No (\%) \\
\hline Simple hyperplasia (S.H) & $14(28.0)$ \\
\hline Disordered proliferative endometrium (D.P.E) & $36(72.0)$ \\
\hline Total & $50(100.0)$ \\
\hline
\end{tabular}

Table (8) showed that $28 \%$ of patients in the progesterone group had simple hyperplasia and the remaining $72 \%$ had disordered proliferative endometrium.

Table (9): Pathology of metformin group before and after treatment

\begin{tabular}{|c|c|c|}
\hline \multirow{2}{*}{ Pathology } & \multicolumn{2}{|c|}{ Metformin group } \\
\cline { 2 - 3 } & $\begin{array}{c}\text { Before treatment } \\
\text { No }(\%)\end{array}$ & $\begin{array}{c}\text { After treatment } \\
\text { (transformed to A.E) No (\%) }\end{array}$ \\
\hline Simple hyperplasia (S.H) & $16(32.0)$ & $11 / 16(68.8)$ \\
\hline $\begin{array}{c}\text { Disordered proliferative } \\
\text { endometrium (D.P.E) }\end{array}$ & $34(68.0)$ & $25 / 34(73.5)$ \\
\hline Total & $50(100.0)$ & $36 / 50(72.0)$ \\
\hline
\end{tabular}

A.E: Atrophic Endometrium.

Table (9) showed that after treatment in the metformin group, 11 out of 16 patients $(68.8 \%)$ with simple hyperplasia transformed into atrophic endometrium whereas, 25 out of 34 patients $(73.5 \%)$ with disordered proliferative endometrium transformed into atrophic endometrium.

Table (10): Pathology of progesterone group before and after treatment

\begin{tabular}{|c|c|c|}
\hline \multirow{2}{*}{ Pathology } & \multicolumn{2}{|c|}{ Progesterone group } \\
\cline { 2 - 3 } & $\begin{array}{c}\text { Before treatment } \\
\text { No (\%) }\end{array}$ & $\begin{array}{c}\text { After treatment } \\
\text { (transformed to A.E) No (\%) }\end{array}$ \\
\hline Simple hyperplasia (S.H) & $14(28.0)$ & $10 / 14(71.4)$ \\
\hline $\begin{array}{l}\text { Disordered proliferative } \\
\text { endometrium (D.P.E) }\end{array}$ & $36(72.0)$ & $26 / 36(72.2)$ \\
\hline Total & $50(100.0)$ & $36 / 50(72.0)$ \\
\hline
\end{tabular}

A.E: Atrophic Endometrium.

Table (10) showed that after treatment in the progesterone group, 10 out of 14 patients $(71.4 \%)$ with simple hyperplasia transformed into atrophic endometrium whereas, 26 out of 36 patients $(72.2 \%)$ with disordered proliferative endometrium transformed into atrophic endometrium.

Table (11): Response to medication in metformin and progesterone groups

\begin{tabular}{|c|c|c|c|c|c|}
\hline Group & $\begin{array}{l}\text { Negative } \\
\text { No }(\%)\end{array}$ & $\begin{array}{l}\text { Positive } \\
\text { No }(\%)\end{array}$ & $\begin{array}{c}\text { Total } \\
\text { No }(\%)\end{array}$ & FET & P-value \\
\hline Metformin (No.=50) & $9(18.0)$ & $41(82.0)$ & $50(100.0)$ & \multirow[b]{2}{*}{0.3} & \multirow[b]{2}{*}{0.786} \\
\hline $\begin{array}{l}\text { Progesterone } \\
(\text { No.=50) }\end{array}$ & $7(14.0)$ & $43(86.0)$ & $50(100.0)$ & & \\
\hline Total & $16(16.0)$ & $84(84.0)$ & $100(100.0)$ & & \\
\hline
\end{tabular}

FET: Fisher's Exact Test.

Table (11) showed that $82 \%$ of patients in the metformin group and $86 \%$ of patients in the progesterone group showed positive response to medication with no statistical significant reference.

\section{DISCUSSION}

Our discoveries in this examination uncovered that metformin could be viable just as progesterone in settling of amiable enodometrial proliferative injuries.

Our outcomes were in accordance with past preclinical investigations respect to hostile to proliferative job of metformin responsible for endometrial cell development ${ }^{(11)}$.
As a rule the considerate injuries normally actuated by hormonal imbalance (unopposed estrogen) though the premalignant multiplication brought about by monoclonal development and transformation of tumor-silencer qualities in the influenced organs. The executives relies upon the kind of hidden sickness, histologic finding, regenerative status of the lady, regardless of whether the patient is on hormone substitution treatment or not 
and her general wellbeing. Amiable endometrial hyperplasia reacts well to medroxyprogesterone acetic acid derivation (MPA), $10 \mathrm{mg}$ orally, or micronized progesterone, $300 \mathrm{mg}$ orally, when daily for 14 days out of each month for 3 months. Such cyclic regimens lead to withdrawal dying; a biopsy example is gotten toward the finish of the progestin treatment at 3-4 months. Complete responders ought to be kept up on cyclic progesterone treatment or, if fitting, consolidated cyclic or persistent HRT. On the off chance that a halfway reaction is gotten, an additional 3-month preliminary with MPA, $10 \mathrm{mg}$ orally four times each day, or megestrol acetic acid derivation, $80 \mathrm{mg}$, for 3 months might be completed. Non-responders and patients with immovable leap forward draining may have transabdominal hysterectomy ${ }^{(14)}$.

In the new plan for endometrial proliferative issue and precancerous sores, DPE and EH without atypia were incorporated into benevolent classification with no dangerous potential and endometrial intrepithelial neoplasia (EIN) considered as a genuine precancerous sore with noteworthy relationship of coexistance or subseqent endometrial endometriod carcinoma ${ }^{(15)}$.

In a partner study directed by Libby $\boldsymbol{e t}$ al.$^{(13)}$, they found that disease rate in metformin client diabetic patients were altogether lower than the diabetic patients who were never on metformin in the wake of modifying for age, sex, A1c hemoglobin, hardship, smoking and other medication use.

The conceivable component of antiproliferative impact of metformine lies in initiating of AMPK pathway and improves enactment of AMPK by LBK1 which lead to bringing down of cell vitality level for tumoral expansion. Ongoing research center confirmations demonstrating that three unmistakable medications (AMPK-activator) postponed tumorigenesis in tumor-inclined mice. This discovery recommends that AMPK activators could have restorative advantage for the treatment of malignancy in people ${ }^{(11)}$. In another examination the agents demonstrated that metformin goes about as a foe to testosterone on endometrial glandular cell line and presumed that metformin could be compelling in settling of insulin opposition impact of high androgen level in PCO patients ${ }^{(14)}$.

All of 22 patients aside from one in metformin gathering react great and histology of the endometrium convert to atrophic endometrium. In spite of the fact that the present investigation has been centered on the antiproliferative impact of metformin in amiable endometrial injuries, nearness of 2 and three patients with EEC and $\mathrm{CH}$ in metformin bunch (presumably for fruitfulness want reason) demonstrate that this prescription could be successful in reestablishing latent endometrium in threatening or premalignant conditions. This restricted finding was in accordance with discoveries of an ongoing report in regards to against cancer-causing impact of metformin ${ }^{(16)}$.

Regardless of whether it may apply its impacts through effect on miRNAs ${ }^{(17)}$ is an inquiry, which requires consideration.

\section{CONCLUSION}

The current study showed that treatment of the patients with abnormal endometrial proliferation (DPE and $\mathrm{SH}$ ) with metformin induced endometrial atrophy could prevents abnormal cell growth and prevents perimenopausal bleeding subsequently.

\section{REFERENCES}

1. Acmaz G, Aksoy H, Albayrak E et al. (2014): Evaluation of endometrial precancerous lesions in postmenopausal obese women-a high risk group. Asian Pac J Cancer Prev., 15(1):195-8.

2. Dizon DS (2010): Treatment options for advanced endometrial carcinoma. Gynecol Oncol., 117:373-81.

3. Thigpen JT, Brady MF, Alvarez RD et al. (1999): Oral medroxyprogesterone acetate in the treatment of advanced or recurrent endometrial carcinoma: a dose-response study by the Gynecologic Oncology Group. Journal of Clinical Oncology, 17(6):1736-.

4. Daniel AR, Knutson TP, Lange CA (2009): Signaling inputs to progesterone receptor gene regulation and promoter selectivity. Molecular and Cellular Endocrinology, 308(1-2):47-52.

5. Calle EE, Rodriguez $\mathrm{C}$, Walker-Thurmond $\mathrm{K}$ et al. (2003): Overweight, obesity, and mortality from cancer in a prospectively studied cohort of US adults. New England Journal of Medicine, 348(17):1625-38.

6. Giudice LC (2006): Endometrium in PCOS: implantation and predisposition to endocrine CA. Best Pract Res Clin Endocrinol Metab., 20:235-44.

7. Lemay A, Dodin S, Turcot L et al. (2005): Rosiglitazone and ethinyl estradiol/cyproterone acetate as single and combined treatment of overweight women with polycystic ovary syndrome and insulin resistance. Human Reproduction, 21(1):121-8.

8. Bjørge T, Lukanova A, Jonsson $H$ et al. (2010): Metabolic syndrome and breast cancer in the me-can (metabolic syndrome and cancer) project. Cancer Epidemiology and Prevention Biomarkers, 19(7):1737-45.

9. Tan BK, Adya R, Chen J et al. (2011): Metformin treatment exerts antiinvasive and antimetastatic effects in human endometrial carcinoma cells. The Journal of Clinical Endocrinology \& Metabolism, 96(3):808-16.

10. Campagnoli $C$, Abbà $C$, Ambroggio $S$ et al. (2013): Lifestyle and metformin for the prevention of endometrial pathology in postmenopausal women. Gynecological Endocrinology, 29(2):119-24.

11. Huang $X$, Wullschleger $S$, Shpiro $N$ et al. (2008): Important role of the LKB1-AMPK pathway in suppressing tumorigenesis in PTEN-deficient mice. Biochemical Journal, 412(2):211-21.

12. Jarboe EA and Mutter GL (2010): Endometrial intraepithelial neoplasia. Semin Diagn Pathol., 27: 215-25.

13. Libby G, Donnelly LA, Donnan PT et al. (2009): New users of metformin are at low risk of incident cancer: a cohort study among people with type 2 diabetes. Diabetes care, 32(9):1620-5. 
14. Zhang ZJ, Zheng ZJ, Kan $H$ et al. (2011): Reduced risk of colorectal cancer with metformin therapy in patients with type 2 diabetes: a meta-analysis. Diabetes care, 34(10):2323-8.

15. Wheeler DT, Bristow RE, Kurman RJ (2007): Histologic alterations in endometrial hyperplasia and welldifferentiated carcinoma treated with progestins. The American journal of surgical pathology, 31(7):988-98.
16. Ko EM, Walter P, Jackson A et al. (2014): Metformin is associated with improved survival in endometrial cancer. Gynecol Oncol., 132: 438-42.

17. Avci CB, Harman E, Dodurga Y et al. (2013): Therapeutic potential of an anti-diabetic drug, metformin: alteration of miRNA expression in prostate cancer cells. Asian Pac J Cancer Prev., 14: 765-8. 